\title{
THE SONG IS ENDED BUT THE MELODY LINGERS ON ${ }^{1}$
}

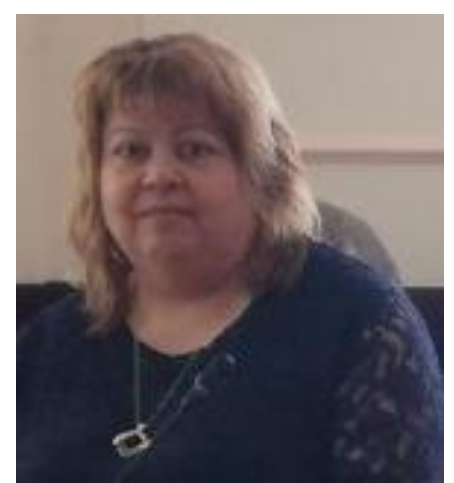

\section{Biographical-Item of prof. Dr. Milena Tepavicharova}

In 1997 she completed a master's degree in Music Pedagogy at Plovdiv University "Paisii Hilendarski", and in 2004 she obtained a master's degree in Public Finance at the University of National and World Economy in Sofia.

In 2011 he defended his dissertation on "Human Resources Management in the Agricultural Sector" at the Department of Administration and Management of the Agricultural University - Plovdiv, published the same year.

Since 2009 he has been a lecturer in macro- and microeconomics and human resources management at the HSSE - Plovdiv and actively participates in the construction of the new curricula in the field of economics.

In 2015 she was elected to the academic position "Associate professor" in the scientific specialty "Organization and Management of Production", then she was elected as a Dean of the Scientific and Research Center "Economics and Management" of HSSE-Plovdiv. In 2017 she was elected to the academic position "Professor" of HSSE -Plovdiv, in the field 3. Social, economic and legal sciences, professional field 3.7. "Administration and Management".

Prof. Tepavicharova is the author of 4 monographs, 15 studies, 150 articles and study materials and books, developing basic principles of the organization and strategic management of human resources with a view to their effective improvement. A significant part of her research is in the field of benchmarking, as a tool for increasing the efficiency and competitiveness of business organizations, social entrepreneurship, communication policies, management of the public sector.

Prof. Tepavicharova shares her scientific potential and professionalism with many scientists, both from Bulgaria and Russia, Latvia and Poland. Her publications are available to scientists and are indexed in global scientometric databases, journals with the highest scientific level in Scopus and the Web of science.(6 articles in Scopus, $\mathrm{H}=4,44$ citation). She is an author and reviewer in journals with impact factor / rank, including those in the top $10 \%$ of those indexed with Q1.

\footnotetext{
${ }^{1}$ Irving Berlin
} 
She works wholeheartedly and diligently with his students, and sincerely rejoices in their successes. It was the students who were until recently the thoughts and deeds of Prof. Milena Tepavicharova.

The Bulgarian scientific circles suffered a heavy loss of one such spiritually rich person with a serious contribution to the development of the science of human resource management, in the popularization of its phenomena and in the transmission of classical management in our time.

\section{A bow to her bright memory!}

\section{Prof. PhD. Valentina Nikolova-Alexieva,}

Dean of the Faculty of Economics

University of Food Technologies-Plovdiv, Plovdiv, Bulgaria 